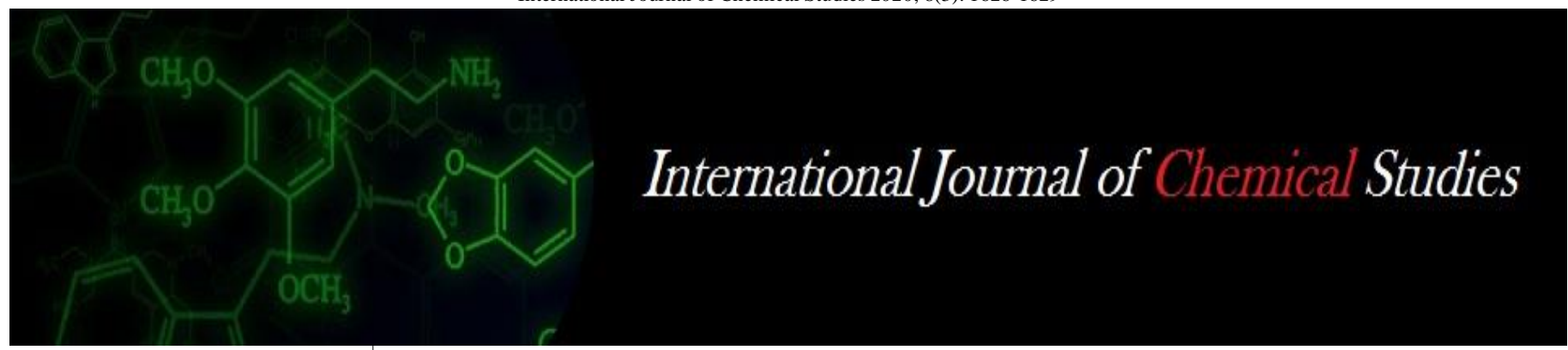

P-ISSN: 2349-8528

E-ISSN: 2321-4902

www.chemijournal.com

IJCS 2020; 8(3): 1626-1629

(C) 2020 IJCS

Received: 18-03-2020

Accepted: 20-04-2020

Basavanneppa MA

Chief Agronomist and Head,

Agriculture Research Station,

Siruguppa, Karnataka, India

Prakash H Kuchanur

Professor and Head, Department of Genetics and Plant Breeding, Collage of Agriculture,

Bheemarayanagudi, Karnataka, India

Corresponding Author: Basavanneppa MA

Chief Agronomist and Head, Agriculture Research Station, Siruguppa, Karnataka, India

\section{Productivity and profitability of maize as influenced by genotypes, spacing and nutrient levels under irrigated situation}

\author{
Basavanneppa MA and Prakash H Kuchanur
}

DOI: https://doi.org/10.22271/chemi.2020.v8.i3v.9428

\begin{abstract}
A field experiment was conducted on "Productivity and profitability of maize as influenced by genotypes, pacing and nutrient levels under irrigated situation" during the Kharif 2019 at Agriculture Research Station, Siruguppa, Karnataka, India. It is situated on the latitude of $15^{\circ} 38^{\prime}$ N, longitude $76^{\circ} 54^{\prime}$ E, $380 \mathrm{~m}$ elevation from MSL belongs to Northern Dry Zone (Zone 3) of Karnataka. The soil of the experimental site was medium deep black cotton soil with organic carbon content of 0.43 per cent, low in available $\mathrm{N}\left(226 \mathrm{~kg} \mathrm{ha}^{-1}\right)$, medium in available phosphorus $\left(18 \mathrm{~kg} \mathrm{ha}^{-1}\right)$ and high in potassium $(380 \mathrm{~kg} \mathrm{ha}$ $\left.{ }^{1}\right)$ content. Trail consisting 12 treatment combinations of 3 genotypes viz. $V_{1}$ : GPMH 1101, V $\mathrm{V}_{2}$ GH 0727 and $\mathrm{V}_{3}$ : RCRMH 4 in main plots, two spacing $S_{1}: 60 \mathrm{~cm} \times 20 \mathrm{~cm}$ and $S_{2}: 45 \mathrm{~cm} X 20 \mathrm{~cm}$ in sub plots and two nutrient levels $F_{1}: 150: 75: 37.5 \mathrm{~kg} \mathrm{NPK} / \mathrm{ha}$ and $F_{2}: 225: 112.5: 56.5 \mathrm{~kg} \mathrm{NPK} / \mathrm{ha}$ in sub-sub plots laid out in split-split plot design and replicated three times. The experimental results revealed that, among the genotypes, RCRMH 4 recorded higher maize grain $\left(8939 \mathrm{~kg} \mathrm{ha}^{-1}\right)$, stover yield (14167 kg ha-1) compared to other genotypes. Spacing did not influenced on grain and stover yield. Maize fertilized with $225: 112.56 .5 \mathrm{~kg}$ NPK/ha registered significantly superior grain $(8085 \mathrm{~kg} / \mathrm{ha})$ and stover yield $(13013$ $\mathrm{kg} / \mathrm{ha}$ ) than lower dose. Similarly, maximum gross return (Rs. 140249/ha), net return (Rs.110651/ha) with B: C (4.75) was recorded in RCRMH 4 compared to other genotypes. Application of 225:112.5:56.5 $\mathrm{kg} \mathrm{NPK/ha}$ gave higher gross, net returns and B: C of Rs. 126989 /ha, Rs. 96034/ha and 4.11, respectively than lower fertilizer dose. Similar trend in cob weight, 100 seed weight, cob length, cob girth, number of grain rows per cob and grain rows per cob were observed in RCRMH 4 and higher dose of fertilizer compared to rest of the genotypes and fertilizer level. But, spacing did not significantly influence on monetary returns.
\end{abstract}

Keywords: Maize, genotypes, spacing, fertilizer levels, grain and stover yield, yield parameters, gross return, net return and $\mathrm{BC}$ ratio.

\section{Introduction}

Maize (Zea mays L.) is an important cereal crop in the world and contributes to food security in most of the developing countries. Globally, it is popularly known as queen of cereals due to its highest genetic yield potential among the cereals. Maize is emerging as third most important crop In India after rice and wheat. Since it is having wider adaptability under varied agro-climatic conditions and it can be cultivated in different seasons and ecologies for multiple purposes. At present, out of the total maize produced, nearly 55 per cent is used as food, about 14 per cent for livestock, 18 per cent for poultry feed, 12 per cent for starch and one per cent as seed. Maize consists of 71.5 per cent starch, 1.9 per cent protein, 4.8 per cent fat and 1.4 per cent ash (Rathore, 2001) ${ }^{[11]}$. It is not only used as human food and animal feed but at the same time it is also widely used in corn starch industry, corn oil production, and as baby corn in different recipes also (Singh, 2014) ${ }^{[14]}$. Maize is being cultivated in an area of $10.2 \mathrm{~m}$ ha with a production of $26.2 \mathrm{~m} \mathrm{t}$ with an average productivity of $2.57 \mathrm{t} \mathrm{ha}^{-1}$ in India, and it is being the fourth largest producer in the world contributing three percent of the global production (Anon., 2017) ${ }^{[2]}$. In Karnataka, it occupies an area of 12.67 lakh ha with a production of $3.31 \mathrm{~m} \mathrm{t}$ and an average productivity of $2.6 \mathrm{t} \mathrm{ha}^{-1}$ (Anon., 2016) ${ }^{[1]}$.

The main aim of agronomists is to achieve higher grain yield of crops either in rainfed or in irrigated ecosystem through maintenance of optimum plant density is the most important factor. A spatial arrangement of plant governs the shape and size of the leaf area per plant, 
which in turn influences efficient interception of radiant energy as well as proliferation and growth of roots and their activity. Maximum yield can be expected only when plant population allows individual plant to achieve their maximum inherent potential. Therefore, there is need to work out an optimum population density by adjusting inter and intra row spacing in relation to other agronomic factors. In addition judicious use of fertilizer is a key to get higher maize yield as they alone contribute 40-60 per cent of the crop yield (Mathukai, 2014) [6]. Maize is known for its nutrient exhaustive crop and requires huge quantities of nitrogen and phosphorus. Besides, every year either public or private sectors are releasing new genotypes both in India as well as in Karnataka state also. These newly released genotypes have the potential to give more yields. In this context agronomic practices such as seed rate, plant population and fertilizer management are known to affect crop environment, which influence the growth and ultimately the yield (Lomte and Khuspe, 1987) ${ }^{[5]}$. Keeping all these points in view, the present investigation was carried out to study the productivity and profitability of maize genotypes as influenced by spacing and nutrient levels under irrigated situation.

\section{Materials and methods}

A field experiment was conducted on "Productivity and profitability of maize as influenced by genotypes, pacing and nutrient levels under irrigated situation" during the Kharif 2019 at Agriculture Research Station, Siruguppa, Karnataka, India. It is situated on the latitude of $15^{\circ} 38^{\prime} \mathrm{N}$, longitude 76 $54^{\prime}$ ' E, $380 \mathrm{~m}$ elevation from MSL belongs to Northern Dry Zone (Zone 3) of Karnataka. The soil of the experimental site was medium deep black cotton soil with organic carbon content of 0.43 per cent, low in available $\mathrm{N}\left(226 \mathrm{~kg} \mathrm{ha}^{-1}\right)$, medium in available phosphorus $\left(18 \mathrm{~kg} \mathrm{ha}^{-1}\right)$ and high in potassium $\left(380 \mathrm{~kg} \mathrm{ha}^{-1}\right)$ content. Trail consisting 12 treatment combinations of 3 genotypes viz. $\mathrm{V}_{1}$ : GPMH 1101, $\mathrm{V}_{2}$ : GH 0727 and $V_{3}$ : RCRMH 4 in main plots, two spacing $S_{1}: 60 \mathrm{~cm}$ $\mathrm{X} 20 \mathrm{~cm}$ and $S_{2}: 45 \mathrm{~cm} \mathrm{X} 20 \mathrm{~cm}$ in sub plots and two nutrient levels $F_{1}: 150: 75: 37.5 \mathrm{~kg} N P K / h a$ and $F_{2}: 225: 112.5: 56.5 \mathrm{~kg}$ $\mathrm{NPK} /$ ha in sub-sub plots laid out in split-split plot design and replicated three times. All the other agronomic practices were kept normal and uniform for all the treatments. At crop maturity observations on desired parameter were recorded using standard procedures. The data collected were statistically analyzed by using Fisher's analysis of variance technique and treatment means were compared by LSD (Steel and Torrie, 1984) ${ }^{[16]}$.

\section{Results and discussion \\ Effect of genotypes, spacing and fertilizer levels on yield}

Maize yield was greatly influenced by genotypes, spacing and fertilizer levels (Table 1). The results revealed that among the genotypes, RCRMH 4 recorded significantly higher maize grain (8939 $\mathrm{kg} \mathrm{ha}^{-1}$ ) and stover yields (14167 $\mathrm{kg} \mathrm{ha}^{-1}$ ) compared to other genotypes. The magnitude of increase in grain yield with RCRMH 4 was to the extent of 17.1 to 32.3 over GH0727 and GPMH1101, respectively. This might be due to genetic makeup of the plant, internally morphological characters and insect, disease resistance coupled with higher values of yield attributing parameters (Vishuddha, 2015) ${ }^{[17]}$ and (Sharanabasappa and Basavanneppa, 2019) ${ }^{[12]}$. Among the spacing, even though there were no significant differences in the maize grain and stover yields. However, $60 \mathrm{~cm}$ x $20 \mathrm{~cm}$ produced numerically higher grain $(7697 \mathrm{~kg} / \mathrm{ha})$ and stover yields $(11824 \mathrm{~kg} / \mathrm{ha})$ compared to $45 \mathrm{~cm} \times 20 \mathrm{~cm}$. This might be due to plant receive more sunlight by the canopy of plant and sufficient nutrient from the soil which results higher growth of plant and maximum yield attributes (Rao, 2010 ${ }^{[9]}$ and Vishuddha, 2015) ${ }^{[17]}$. In the present study maize fertilized with 225:112.5:56.5 $\mathrm{kg} \mathrm{NPK} / \mathrm{ha}$ registered significantly superior grain yield (8085 kg/ha) and stover yields (13013 $\mathrm{kg} / \mathrm{ha}$ ) compared to application of $150: 75: 37.5 \mathrm{~kg} \mathrm{NPK} \mathrm{ha}^{-1}$ (6850 $\mathrm{kg} \mathrm{ha}^{-1}$ and $10610 \mathrm{~kg} \mathrm{ha}^{-1}$, respectively). This might be due to the fact that higher levels of NPK led to adequate supply of nutrients to the plant resulting in better growth which in turn led to better physiological process and movement of photosynthates to sink. These results are in cognizance with findings of Paramasivan et al. (2011) [8], Vishuddha (2015) ${ }^{[17]}$ and Sharanabasappa and Basavanneppa (2019) ${ }^{[12]}$. In a study conducted by Rashid and Ryan (2004) ${ }^{[10]}$ at Faisalabad Pakistan revealed that maize crop fertilized with @ 250: 150: 100: 15 NPKS kg/ha produced significantly more grain yield (8.52 t ha-1), stover yields (12.08 t ha-1), in the present study, the interaction effect between genotypes, spacing and fertilizer levels were not significant.

Table 1: Grain yield and yield parameters of maize as influenced by genotypes, spacing and fertilizer levels in irrigated situation

\begin{tabular}{|c|c|c|c|c|c|c|c|c|}
\hline Treatments & \begin{tabular}{|c|}
$\begin{array}{c}\text { Grain yield } \\
(\mathrm{kg} / \mathrm{ha})\end{array}$ \\
\end{tabular} & $\begin{array}{c}\text { Stover yield } \\
\text { (kg/ha) }\end{array}$ & \begin{tabular}{|c|} 
Cob w \\
(g)
\end{tabular} & \begin{tabular}{c|} 
Cob length \\
$(\mathrm{cm})$
\end{tabular} & $\begin{array}{c}\text { Cob girth } \\
(\mathrm{cm})\end{array}$ & $\begin{array}{c}\begin{array}{c}\text { No of grain } \\
\text { rows/cob }\end{array} \\
\end{array}$ & \begin{tabular}{|c|}
$\begin{array}{c}\text { No. of } \\
\text { grains/row }\end{array}$ \\
\end{tabular} & $\begin{array}{c}100 \text { seed wt } \\
(\mathrm{g})\end{array}$ \\
\hline \multicolumn{9}{|c|}{ Genotypes(V) } \\
\hline V1:GPMH1101 & 6052 & 9809 & 596 & 12.28 & 12.54 & 13.42 & 27.33 & 24.11 \\
\hline V2:GH0727 & 7411 & 11457 & 668 & 13.74 & 13.56 & 13.80 & 29.13 & 27.19 \\
\hline V3:RCRMH4 & 8939 & 14167 & 748 & 16.05 & 13.54 & 13.67 & 33.14 & 26.22 \\
\hline $\mathrm{S} \mathrm{Em} \pm$ & 149 & 173 & 5 & 0.073 & 0.073 & 0.068 & 0.112 & 0.039 \\
\hline C.D@ @ $5 \%$ & 585 & 680 & 19 & 0.286 & 0.288 & 0.267 & 0.440 & 0.154 \\
\hline \multicolumn{9}{|c|}{ Spacings } \\
\hline S1: $60 \times 20 \mathrm{~cm}$ & 7237 & 11798 & 704 & 14.34 & 13.13 & 13.23 & 31.39 & 26.73 \\
\hline $\mathrm{S} 2: 45 \times 20 \mathrm{~cm}$ & 7697 & 11824 & 637 & 13.71 & 13.29 & 14.02 & 28.35 & 24.91 \\
\hline $\mathrm{S} \mathrm{Em} \pm$ & 164 & 62 & 5 & 0.048 & 0.053 & 0.031 & 0.078 & 0.056 \\
\hline C.D@ $9 \%$ & NS & 216 & 16 & 0.168 & NS & 0.109 & 0.271 & 0.192 \\
\hline \multicolumn{9}{|c|}{ Fertilizer management } \\
\hline F1:150:75:37.5 kg NPK/ha & 6850 & 10610 & 604 & 13.86 & 12.97 & 13.43 & 29.27 & 24.59 \\
\hline F2: $225: 112.5: 56.5 \mathrm{~kg}$ NPK/ha & 8085 & 13013 & 738 & 14.19 & 13.47 & 13.82 & 30.47 & 27.22 \\
\hline $\mathrm{S} \mathrm{Em} \pm$ & 121 & 83 & 4 & 0.036 & 0.039 & 0.046 & 0.065 & 0.120 \\
\hline C.D@ @ $5 \%$ & 374 & 257 & 12 & 0.110 & 0.119 & 0.142 & 0.200 & 0.369 \\
\hline \multicolumn{9}{|c|}{ Interactions (VxSxF) } \\
\hline $\mathrm{S} \mathrm{Em} \pm$ & 717 & 518 & 23 & 0.241 & 0.255 & 0.250 & 0.403 & 0.532 \\
\hline C.D@ @ $5 \%$ & NS & 1810 & 75 & 0.841 & NS & 0.841 & 1.383 & 1.664 \\
\hline
\end{tabular}




\section{Effect of genotypes, spacing and fertilizer levels on yield parameters}

Yield attributes viz; cob length, cob girth, cob weight, number of grains rows per cob, number of grains per row and 100 seed weight significantly influenced by genotypes, spacing and fertility levels present in Table 1. The maximum yield attributes were obtained with maize genotype (RCRMH 4) compared to other genotypes. Better performance of yield attributes in $60 \mathrm{~cm} \times 20 \mathrm{~cm}$ spacing was mainly due to better availability of resources such as sunshine, movement of air and availability of nutrients than the narrow spacing $45 \mathrm{~cm} \mathrm{x}$ $20 \mathrm{~cm}$. Similar findings were reported by Laskari et al. (2011) ${ }^{[4]}$,Vishuddha (2015) [17] and Sharanabasappa and Basavanneppa(2019) ${ }^{[12]}$. The cob length $(14.19 \mathrm{~cm})$, cob girth $(13.47 \mathrm{~cm})$, cob weight $(739 \mathrm{~g})$ number of grain rows/cob (13.82), number of grains/row (30.47) and 100 seed weight $(27.22 \mathrm{~g})$ were significantly more in maize fertilized with 225:112.5:56.5 kg NPK/ha than application of lower dose. This might be due to adequate supply of nutrients results in improve the overall growth of the plants. These results are in agreement with the findings of Vishuddha (2015) ${ }^{[17]}$ and Sharanabasappa and Basavanneppa (2019) ${ }^{[12]}$. In another study conducted elsewhere by Panchannathan et al. (1987) ${ }^{[7]}$ reported that application of $120 \mathrm{~kg} \mathrm{~N} / \mathrm{ha}$ recorded maximum number of grains per cob, cob length, cob girth and 1000 grain weight, which was at par with application of $180 \mathrm{~kg} \mathrm{~N}$ /ha but significantly higher than $60 \mathrm{~kg} \mathrm{~N} / \mathrm{ha}$ and no nitrogen.

\section{Effect of spacing and fertilizer levels on profitability}

Among the maize genotypes, RCRMH4 recoded significantly higher gross return (Rs. 140249/ha), net return (Rs. 110651/ha) and BC ratio (4.75) than other genotypes. This was mainly attributed to higher grain and stover yield. Magnitude of increase in net return under RCRMH 4 was ranged from 21.9 to 40.8 per cent over GH0727 and GPMH1101, respectively (Table 2). Spacing did influence on the monetary returns. Maximum gross returns, net returns and BC ratio (Rs. 126989/ha, Rs. 96034/ha and 4.11, respectively) was recorded with the application of 225:112.5:56.5 NPK $\mathrm{kg} / \mathrm{ha}$ compared lower fertilizer level and it was mainly due to production of higher maize grain and stover yields. These results are in conformity with findings of Ashwani et al. (2015) ${ }^{[3]}$ and Sharanabasappa et al. (2017) ${ }^{[13]}$. In another study conducted by Singh et al. (2010) ${ }^{[15]}$ reported that net return and $\mathrm{B}$ : $\mathrm{C}$ increased significantly with successive increase in fertility level of $180+38.7+74.7 \mathrm{~kg} \mathrm{~N}+\mathrm{P}+\mathrm{K}$ per hectare in baby corn. In the present study interaction effect between genotypes, spacing and fertilizer levels were found non-significant.

Table 2: Monetary returns of maize as influenced by genotypes, spacing and fertilizer levels in irrigated situation

\begin{tabular}{|c|c|c|c|c|}
\hline Treatments & Cost of cultivation (Rs./ha) & Gross returns (Rs./ha) & Net returns (Rs./ha) & B:C \\
\hline \multicolumn{5}{|c|}{ Genotypes(V) } \\
\hline V1:GPMH1101 & 29598 & 95115 & 65517 & 3.21 \\
\hline V2:GH0727 & 29598 & 116049 & 86451 & 3.90 \\
\hline V3:RCRMH4 & 29598 & 140249 & 110651 & 4.75 \\
\hline $\mathrm{S} \mathrm{Em} \pm$ & & 2196 & 2196 & 0.072 \\
\hline C.D@ @ $5 \%$ & & 8621 & 8621 & 0.284 \\
\hline \multicolumn{5}{|c|}{ Spacings } \\
\hline S1: $60 \times 20 \mathrm{~cm}$ & 30060 & 113791 & 83731 & 3.78 \\
\hline S2: $45 X 20 \mathrm{~cm}$ & 29136 & 120484 & 91348 & 4.13 \\
\hline $\mathrm{S} \mathrm{Em} \pm$ & & 2397 & 2397 & 0.081 \\
\hline C.D@ @ $5 \%$ & & NS & NS & 0.282 \\
\hline \multicolumn{5}{|c|}{ Fertilizer management } \\
\hline F1:150:75:37.5 kg NPK/ha & 28241 & 107286 & 79045 & 3.80 \\
\hline F2: $225: 112.5: 56.5 \mathrm{~kg} \mathrm{NPK} / \mathrm{ha}$ & 30955 & 126989 & 96034 & 4.11 \\
\hline S Em \pm & & 1764 & 1764 & 0.059 \\
\hline C.D@ @ $5 \%$ & & 5437 & 5437 & 0.182 \\
\hline \multicolumn{5}{|c|}{ Interactions (VxSxF) } \\
\hline $\mathrm{S} \mathrm{Em} \pm$ & & 10478 & 10478 & 0.351 \\
\hline C.D@ @ $5 \%$ & & NS & NS & NS \\
\hline
\end{tabular}

\section{Conclusion}

Maize genotype RCRMH4 gave significantly higher maize grain yield, stover yield, gross return, and net returns and BC ratio compared to other genotypes. Application of 225:112.5:56.5 NPK kg/ha was registered significantly higher grain, stover yield, gross return, net return and $\mathrm{BC}$ ratio compared to lower fertilizer level.

\section{Acknowledgements}

The author wish to express his appreciation to Indian Institute of Farming System Research, Modipuram (UP) and University of Agricultural Sciences, Raichur for their kind financial support offered during the course of investigation.

\section{References}

1. Anonymous. Annual report of Indian institute of maize Research. ICAR New Delhi, 2016.
2. Anonymous. Annual report of Indian institute of maize Research. ICAR New Delhi, 2017.

3. Ashwani KT, Dushyant ST, Rakesh KP, Adikant P, Prafull K. Effect of different plant geometry and nitrogen levels in relation to growth characters, yield and economics on sweet corn (Zea mays sachharata L.) at Bastar plateau zone. International Quarterly Journal of Life Science. 2015; 10(3):1223-1226.

4. Laskari Mojgan, Madani Hmid, Ardakani Mohammad Reza, Golarardi Farid, Zargari Keveh. Effect of plant density on yield and yield components of different corn (Zea mays L.) hybrids. American- Eurasian Journal of Agriculture and Environmental Science. 2011; 10(3):450457.

5. Lomte MH. Khuspe VS. Effect of plant densities, P levels and antitranspirants on the yield of summer groundnut. Journal of Maharashtra Agricultural Universities. 1987; 12(1):28-30. 
6. Mathukia RK. Choudhary RP. Ashish Shivran. Nilima Bhosale. Response of Rabi sweet corn to plant geometry and fertilizer. Current Biotica. 2014; 7(4):294-298.

7. Panchanathan RM. Mohandas S. Kandaswamy P. Effect of moisture regimes and nitrogen application on maize. Indian Journal of Agronomy. 1987; 32:471-472.

8. Paramasivan M, Kumaresan KR, Malarvizhi S, Thiyageswari S, Mahimairaja Velayudham K. Nutrient optimization strategy for sustainable productivity of hybrid maize (Zea mays L.) in palaviduthi (Pvd) series of soil science of Tamil Nadu. Research on Crops. 2011; 12(1):39-44.

9. Rao G. Response of baby corn genotypes to plant density and fertilizer. M.Sc. thesis submitted to University of Agricultural Sciences, Dharwad, Karnataka, 2010.

10. Rashid A. Ryan J. Micronutrients constraints to crop production in soils with Mediterranean-type characteristics: A review. Journal of Plant Nutrition. 2004; 27(6):959-975.

11. Rathore MD. Ecology of common insect pests of Rice. Annual Review of Entomology. 2001; 13:257-294.

12. Sharnabasappa HC. Basavanneppa MA. Influence of plant population and fertilizer levels on growth, yield and quality parameters of quality protein maize (Zea mays L.) in irrigated ecosystem. International Journal of Chemical Studies. 2019; 7(2):1425-1429.

13. Sharanabasappa HC, Basavanneppa MA, Koppalkar BG, Latha HS, Balanagoudar SR. Effect of plant density and fertilizer levels on yield and economics of quality protein maize (zea mays 1.) under irrigated condition. International Journal of Science and Nature. 2017; 8(1):128-131.

14. Singh AD. Maize in India. India Maize Summsit. FICCI, 2014, 2p.

15. Singh MK, Singh RN, Singh SP, Yadav MK, Singh VK. Integrated nutrient management for higher yield, quality and profitability of baby corn (Zea mays). Indian Journal of Agronomy. 2010; 55(2):100-104.

16. Steel RGD, Torrie H. Principles and Procedures of Statistics, 2nd Ed. Mc Graw Hill International book Co., Singapore, 1984, 172-177.

17. Vishuddha N. Effect of spacing and fertility levels on protein content and yield of hybrid and composite maize (Zea mays L.) grown in rabi season. Journal of Agriculture and Veterinary Science. 2015; 8(9):26-31. 